\title{
Intertextuality and African Writers
}

\begin{abstract}
It is a general misconception in some quarters that influence of one literary work on others is a denial of the author's claim to originality. That a writer influences another author does not mean that the newly produced work lacks originality. In fact, that act shows resourcefulness of the influenced author. This paper ascertains that intertextuality is established in the works of upcoming African writers and the mastery of its application greatly helps to boost the confidence and maturity of the writers as exemplified in Fágúnwà's novels. The influence of some artists on the literary productions of other writers is explored. With proper acknowledgment, the terrifying ghost of plagiarism is nailed to the cross by the writer. This study concludes that no writer could actually claim that he has not been influenced by one writer or the other. Therefore, borrowing is not a literary sin but failure to acknowledge others' influence on you is hypocritical and condemnable.
\end{abstract}

Key words: intertextuality, African, novel, Fágúnwà, originality, influence, borrowing.

Some African theorists have contributed immensely to the propagation of the theory of intertextuality. Jéyifò (1998:277) posits that "there are configurations and connections between works and writers within the different literary genres.” According to Ode Ogede (2011:201):

African authors may be relatively late comers to the literary scene, but they are not alone in the making of emulation of each other's works as their compositional pattern; as theorists of influence have long made known, intertextuality is a universally accepted practice. This string of connections and configurations between different works and various writers is technically referred to as intertextuality in literature.

Kẹ́hìndé (2003:375) asserts that intertextuality is well established in the works of contemporary African writers. He posits that: "Literature does not evolve within a vacuum. It depends on the socio-political realities of its enabling milieu and the precursor texts (oral/written) for its impetus... African writers also depend on earlier texts for their themes and styles. This is quite pertinent in this era of multiculturalism and globalization" (Kẹ́hìndé (2003: 375).

Writers all over the world depend on earlier texts to fashion out and reconstruct themes and styles in their works. Therefore, there is always a reference from one text to another. This is so because, according to Bọ́dúndé (1994:72), “each literature or text has the capacity to influence 
and extend the meaning of the other." The responsibility lies on literary historians to find out and document how various texts have influenced and extended their meanings in order to discover and establish the thematic and stylistic approaches that are prominent among writers.

On the importance of intertextuality in literary discourse, Izevbaye's (1982:1) comment is an eye-opener when he declares that intertextuality is: "a veritable weapon in the hands of literary historians and critics to establish a relationship among a variety of writers and literatures, and help enhance... understanding of literature as a human activity with similar aesthetic and social functions in different cultures". The influence of an older writer in the literary output or production of the younger author does not mean that the newly produced work lacks originality. It is a general misconception in some scholarly quarters that influence of one literary work on others is a denial of the author's claim to originality of that particular work. For the fact that an older writer influences a new author and that is reflected in the final output of the work does not mean that the newly produced work lacks originality. In fact, that act shows how resourceful the influenced author is in the world of literature. Productivity, maturity and originality in literature is not all about isolation but more of association and influence. To support this view, Randall (2001:106) says, "Borrowing from foreign sources was a form of conquest." A victory on the parts of both the 'influencer' and the 'influenced'. Ogede believes that 'this is one context in which African writers' experience is not entirely antithetical to the situation described for American literature by Harold Bloom in his exploration of the Oedipal theory of art, the condition famously termed by him as the 'acute anxiety of influence' suspected to exist among American literary artists generally." Ogede (2011:2) It makes some sense that the sentiments that lock younger authors in particular in combat with some well-established authors should be especially heightened among minority writers. Ogede (2011:2) says further that: "It is an idea which fatally undermines any ability to understand the fact that originality lies more in what a writer makes of his or her borrowed material-the individual touch that an author can put on his or her inherited".

Whenever the upcoming writers are told that their works lack originality, the heavy burdens of fears and anxieties fall mercilessly on them and that will actually discourage many of them. That act alone might force them to search for ways to conceal their creative motivations. And to be told repeatedly, that a truly original work, rather than being an act of creative negotiation, is a loneranging venture done with no dependence upon or assistance from any quarter, that can throw them off balance, making them psychologically unstable. Also, when they are unfavourably compared with some established writers, those they are judged to be lesser than, that mentality alone has: "left many promising young African writers doubly vulnerable and particularly susceptible to acting as though they are under a compulsion to stake a claim for their own greatness. One crucial fact is thus unknown to, or rather not well understood by many inexperienced African writers: that the plurality of genuinely new works is often pulled from pre-existing texts" (Ogede 2011:2).

The inexperienced African writers are usually prone to harbor unusual anxieties about inspiration. Some of them, due to the unfair criticism of their works, try to distance themselves and avoid anything that can link them to another writer. They equally seek exclusion from the effects 
of others' works as the defining quality of imagination, when they see their own works continually and unfairly compared with those of writers to whom they may feel no connection whatsoever at a conscious level. That has created among many beginning African authors a peculiar feeling of being persistently hunted down to be put on trial for literary theft. Not only that, such situation of distrust has done little to inspire them with confidence in themselves. Indeed, that seems to have reduced the level of African literary production. The young African writers now live with the monster of the possibility of their literary outputs being unfairly torn apart by some literary critics. The emerging authors have to continually contend with a feeling that a "faint ghosts of plagiarism hang over their careers." (Ogede 2011:5). Sembene Ousmane responded to a question he was asked in an interview by David Murphy when his work is compared or linked to another source. To the emphatic question, Ousmane replied angrily. In order to ascertain and re-emphasise his commitment to African course, he posits "But I am African. Why should I go looking for something in the United States? I don't have to search for an identity. I'm an African. For me, Africa is the centre of the world. The United States and Europe are on the periphery of my world." (Murphy 2000: 228).

Among African writers, except a newly produced literary work asserts its own generally acclaimed uniqueness, there is uniform acknowledgment that most literary texts, if not all, take a clue from pre-existing works,. However, being hunted down about the concept of originality, many young and up-coming African writers have a wrong notion that they are in a peculiarly intolerable situation. The situation in which they have the belief that in order to demonstrably establish their own names, the 'hunting shadows' of Western writers as well as the 'ghosts' of their indigenous African predecessors must be confronted. Influence and originality cannot be over-emphasised in any work of art. According to Ogede (2011:5):

It cannot be stressed enough that to be original is simply to possess not only the power to express a new thought or idea but also the capability to articulate one's resources in a uniquely refreshing manner; to demonstrate individuality within contexts or confines imposed by convention; to contribute a genuinely fresh perspective; to be able truly to overcome limits set by what already exists; to put a sense of individual touch on tradition; to be all-inclusively authentic. To invent is to use one's tools responsibly. A primary mindsets up to absorb and it also extends and reorganises all the borrowed stuff which it makes distinctly its own through the creative alchemy of assimilation. Imitation, borrowing, and allusion, except when bordering upon plagiarism and plain stolen words or outright theft, or when done irresponsibly, then, can all be vital components, in differing, varying gradations, of the creative talent.

For instance, although the works of Fágúnwà can be traced to one source or the other, they are not lacking in originality. The influences and the intertextual links have greatly enhanced the wider understanding of Fágúnwà's novels. The theory of intertextuality greatly enhances our understanding of the symbols and allegories in Fágúnwà's novels. For instance, the dreadful character Fear in The Forest of a thousand Daemons, re-echoes in other characters like Ghommid of 
Fear (Ànjònú-ibèrù), Python of Rage (Òjòlá-ibínú), Ẹlẹgbárá, and Àgbákò in Fágúnwàs subsequent novels. Some of these characters and supernatural beings are intertextually referred to in the novels. For the fact that some characters, instances and circumstances mentioned in a particular novel, and are equally referred to in another novel, is not a negation on the originality of the second novel. That does not mean that the second novel is inferior or that it is not artistic enough. As long as such reference is not plagiarism, it proves that the writer knows the rightful application of the theory of intertextuality.

In Myth, Literature, and the African World, Sóyínká (1976:98) puts the perennial debate on novelty in perspective. He submits that an appropriated work can still make "an original contribution to literature, in spite of the borrowings." However, he adds in the same context that "the moral offence" which un-attributed borrowing must be perceived to constitute cannot be made light of.

Originality is what it means for a writer to possess a mind with a distinctive landmark. Intertextuality seems such a useful term because it foregrounds notions of 'relationality', interconnectedness and interdependence in modern cultural life. Sóyínká (1976: 99) argues further:

Imitation of texts or models-a major form of creative interchange-is the central means by which the works of African writers are nurtured and brought into being. African writers seldom work in utter isolation; nor do they have only Western models. Principally because an indigenous canon of literary works with a variety of styles and visions is vigorously being thrust into prominence in the continent, aspiring African authors have many local sources from which to draw.

In the postmodern epoch, theorists often claim, it is not possible any longer to speak of originality or the uniqueness of the artistic object, be it a painting or a novel, since every artistic object is so clearly assembled from bits and pieces of already existent art.

The relationship among texts can be looked at in various ways: it can involve the radical plurality of the sign, the relation between signs and texts and that of the cultural text. The relationship can equally be examined with the relation between a text and the literary system, or the transformative relation between one text and another text. In whatever way it is used, the term intertextuality, according to Ogede (2011: 5), 'promotes a new vision of meaning, and thus, of authorship and reading: a vision resistant to ingrained notions of originality, uniqueness, singularity and autonomy.'

Intertextuality creates a new vision also in the works of Ben Okri as his works are traced to one source or the other, especially The Famished Road. Ògúnsanwó (1995: 45) submits that Okri’s novel is "a distinctive combination of the African and the European which reflects the collective modes of discourse underlying postmodern parody."

Okri's neo-traditional art is not merely making a nostalgic return to the African folktale. It is actually a re-writing of the socio-cultural past in the present in a way that demands critical reinterpretation in anticipation of the future. This re-contextualisation recalls the literary past of the African folktale as an oral art up to the point of its textualisation particularly in Yoruba land. In the interview Okri granted in December, 1990 in London, Jane Wilkinson (1992:88) asks: 
JANE: My personal experience of reading your book was in fact to recall Fágúnwà, Tutùọlá and Sóyínká, but also the vast transnational literature of dream vision and vision generally; forests of the night together with forests of symbols, but also countless forests and labyrinths of literary modem cities.

OKRI: I think when reading the novel one should just think of my primary sources as being the invisible books of spirit. My primary sources are those invisible books. And I mean that very seriously.

Whether Okri admits it or not, some traces of Fágúnwà's vision, sources, style and literary techniques can be located in Ben Okri's literary outputs. However, it is only through intertextuality as part of prior discourse that any text derives meaning and significance. The African oral tradition, from time immemorial, expresses a sense of a shared phenomenal world, both ordinary and extraordinary, to which there has always been a communitarian claim. What traditional literary artists like D. O. Fágúnwà and Amos Tutùolá did was to 'textualise' the shared heritage of the folktale with the creative refashioning that naturally accompanies artistic transmutations from the oral into the written literature. Fágúnwà made his attempts in the Yorùbá language, while Tutùọlá made his in English of his own coinage or within his linguistic competence.

Another instance of intertextuality can be located in the works of J. P. Clark, Ben Okri and Wọlé Sóyínká. In the perspective of Ògúnsanwó, he believes that a sophisticated intertextuality between oral and written folktale is evident in the works of John Pepper Clark and Wọlé Sóyínká. The basic ingredient in their two poems titled "Àbíkú", which is premised on the Yoruba myth of 'Abiku' has equally made the central motif of Okri's The Famished Road very popular and scholarly accepted. This myth, according to Kệhìndé (2003:380), is still a popular one in African literature, most especially among Yoruba writers. Kẹ́hìndé (2003:380) says further that Okri portrays this myth "as a metaphor for the multitude of socio-political and economic problems facing the postcolonial nations. As the Abiku child defies any magical power that can make him stay alive, the myriads of problems facing the African continent and by extension, all neocolonial nations, have defied a lot of solutions. A majority of the nations, despite their political independence, are still encumbered with pains and conflicts." Kệhìndé (2003:380). In fact, "the contrast in the presentation of the 'àbíkú' motif found in Sóyínká's 'Àbíkú' with its overwhelming recalcitrant and cynical tone, and J. P. Clark's "Àbíkú," with its supplicating tone, has been a frequent attraction for the West African Examinations Council's literature examiners, year in-year out, right from the 1960s.” (Ògúnsanwó 1995:46)

Examples of intertextuality abound in African literature. According to Kẹ́hìndé (2003:374) "the theory of intertextuality, despite its Euro-Western origin, is not entirely alien to African oral literary practice." This view is supported by Nwagbara (2011:5) when he declares that "the concept of intertextuality... is not entirely foreign to Nigerian (African) literature and oral tradition.... There is no gainsaying the fact that African oral art and literature are typified by absence of authorial omniscience communal participation/ownership, and group authorship, among others." Likewise, Finnegan's view on the presence of intertextuality in African oral literature is worthy of note. She posits that "such literature was, for instance, supposed to be the work of communal consciousness and group authorship rather than... of an individual inspired artist" (Finnegan 1970:36). 
The experience of intertextuality in African literature has been resourceful. For instance, there is intertextual link between Chinua Achebe's Things Fall Apart (1958) and Joseph Conrad's Heart of Darkness (1902). Achebe's novel gives the readers a very different perception of Africa and African experience from the one portrayed in Conrad's work. In addition, Ngugi's A Grain of Wheat (1967) has intertextual relationship with Conrad's Under Western Eyes (1911) in the area of characterisation. Razumov in Under Western Eyes strives to free himself from poverty and obscurity and is visited by Haldin after an assassination. This is akin to Mugo's situation in A Grain of Wheat where Kihika has to visit him. In the same line, Elechi Amadi's The Concubine (1973) is culturally linked with Achebe's Arrows of God in the area of upholding and promoting African culture and belief; Ngozi Adichie's Purple Hibiscus (2003) is an intertext of political novels depicting military dictatorship as earlier portrayed in Achebe's Anthills of the Savannah (1987).

Further instances of intertextuality in African literature can be seen in Bassie Head's Maru, which is a representation of minorities within an ethnic group and a symbolism of individual change, this can be linked to Chinua Achebe's No Longer at Ease. Also, Achebe's A man of the People, Ngugi's This Time Tomorrow and Armah's The Beautyful Ones are not yet Born are seen to express post-independence disillusionment of the Africans. The South African writer, J. M. Coetzee equally makes use of intertextuality especially in his Foe which can be traced to Daniel Defoe's Robinson Crusoe in the area of the presentation of the black world by Defoe. It can be established that Coetzee is able to "create a new kind of novel that implicitly interrogates the form and content of Defoe's classic. Foe is thus a topological revision of Defoe's text" (Kẹ́hìndé 2003:382). Naguib Mahfouz's Children of Gebelewi, which makes use of traditional epic structure, can also be married to similar epic narratives of J.P. Clark's Ozidi Saga and John Milton's Paradise Lost.

A brief analysis of Fágúnwà's novels shows that examples of intertextuality are established in D.O. Fágúnwà's translated novels. For instance, there are characters like the Sirens whose singing is irresistible and charming in The Forest of a Thousand Daemons and In the Forest of Olódùmarè. Medusa, the Gorgon with snakes instead of hair on her head in Greek myth, is represented in the fearsome character of Fear in The Forest of a Thousand Daemons. (p.84) Fear is the symbolic representation of a character that makes others to be afraid. He is similar in nature to 'Àgbákò', 'Èsùkékeré-òde' and 'Àn jọnú İbẹrù' (ghommid of fear) in In the Forest of Olódùmarè. Other aspects of fear are the religious fear, which we have towards God and Supreme beings and moral fear that is respect or reverence towards our parents, leaders, bosses, and elders in the society. Such a fear makes or breeds cordial relationship but lack of fear or respect for these beings will certainly attract divine wrath. Whosoever despises 'Fear' may not live to tell the story. 'Fear' of whatever kind, either religious or moral, must be accorded its due honour and recognition.

Apart from characters, incidents are taken from classical Greek literature. There is the story of Perseus who engages the Gorgon sisters in battle and carries off Medusa's head that is employed to transform the sea monster into a stone, thereby saving Andromeda. This well-known Greek myth is narrated in Fágúnwà's Irèké Oníbùdó with little modification. The difference is that in Fágúnwà's novel, there is no head, and sword is used to kill the monster. The woman to be sacrificed to the 
monster in both versions is a princess, and the hero eventually marries her. The labyrinth of Crete in which the Minotaur is jailed, which is traceable to another Greek myth features in In the Forest of Olódùmarè. Furthermore, the story of the character turning men into swine and back into men with her magic wand is told in Expedition to the Mount of Thought, which is similar to what obtains in Homer's Odyssey. This is seen in the character called Devil who is able to turn men into all kinds of animals and restore them into their original form again. We can equally liken the travels of Odysseus to the various wanderings of Fágúnwà's heroes from one place to another and from forest to forest.

The story of Lack of Contentment (Kòtẹmilọ́rùn) who takes a disastrous step in reviling God, renouncing Heaven and at last, mortgaging his soul to the Devil, all because of his envy of a friend's wealth is told in Obafemi's (2012) The Mysteries of God. He becomes wealthy at last, but not long after that, Satan kills him and he is taken to Hell. This story recalls the story in Christopher Marlowe's The Tragic History of Doctor Faustus, though there are missing details such as the Wagner scene and the pageants involving Helen, Queen of Troy. In fact, the speeches of both Faustus and Kòtẹmilọ́rùn on their dying beds are similar. Faustus says 'Ah, Faustus. Now hast thou but one hour to live.' Kòtẹmilọ́rùn equally laments, "So it is true that I have only three hours left on this earth" (Obafemi 2012:185).

Another example is the story of two lovers whose parents are sworn enemies and the lovers commit suicide at last due to the suspected death of one lover on the day they plan to elope. He thinks his lover is dead when he sees his lover's dress stained with blood. Consequently, he commits suicide. Shortly after, the second lover emerges from her hideout due to the fear of an approaching lion. Seeing her lover's corpse, she equally kills herself, thinking that the lion has killed her lover. This story is told in Sóyínká's (2010) In the Forest of Olódùmarè and recalls the fate of two lovers in Shakespeare's Romeo and Juliet (1996).

There are references made to smoke turning into a genie and threatening to kill Olówó-aiyé in The Forest of a Thousand Daemons and the king who tells his wife to cook three fishes, which are mysterious in nature in In the Forest of Olódumarè. These stories are traceable to "The Tale of the Fisherman and the Genie" and "The Tale of the Young Man and the Fishes" respectively in Arabian Nights. The names given to these characters, the situations and the myths alluded to are symbolic and allegorical in nature. The story is allegorical in that it moves from the story of a king who tells his wife to cook some fishes for him, to the story of another king who is turned to a living statue by his wicked and adulterous wife. It also has some moral lessons to pass across coupled with symbolic places. The three fishes can be interpreted as symbolising the Muslims, the Christians and the Traditional Worshippers, while the pool the fishes are taken from stands for the world as a whole. In The Forest of a Thousand Daemons, the king determines to resolve the mystery behind the three fishes, which cannot be cooked, and he accomplishes that at last. The same determination and adventurous spirit is seen in the young man's visit to the mysterious pool in "The Tale of the Young man and the Fishes" in Arabian Nights.

The link between these sources in European literature and Fágúnwà's texts is to enhance our understanding. Sellers (2007:41) clinches the argument about the inescapable clutch of effects be- 
queathed by awareness of others' works in this way: "When you imitate, you aren't copying or stealing. You are performing a training exercise, one that has a long and respected tradition in the arts. You of course always acknowledge the imitation. It's against the law to take someone else's words or ideas and pass them off as your own, and it's embarrassing to pretend your work is original when clearly it is not." He submits further:

You are imitating whenever you write, unconsciously. All writers are influenced by the works they have read, what they watch, what they know about literature. Stories you learned as a child are stuck in your head. Phrases and rhythms of works you read last semester lodge in your writing mind, and come out in your work. This is a good thing! Successful writers enjoy embedding subtle references to other pieces of literature in their works. We pass on, translate, adore, and keep alive the writers who influence us, consciously and unconsciously. We're all imitating to some extent; every time we sit down to write. The more widely you read, the more texture your own writing has... If you slavishly read only one or two writers, your work may suffer from a poverty of influence. (Sellers 2007:41)

Sellers reasons, according to Ode Ogede (2011:204) that "it does not really matter how literary imitation is absorbed, whether it is taken in on purpose or not, leverage may occur in ways large or small, manifesting itself subliminally or not so subtly, but it always plays an important, even if cloaked, role in composition; its clutches are seldom entirely avoidable." For instance, just as the symbols in John Bunyan's Pilgrim Progress, like 'the cross', 'the key', 'the valley of Indecision' and 'vanity fair' help the readers to understand the text, so also the symbols and allegory in Fágúnwà's novels like Mount Láńgbòdó, hell, Fear, Helpmeet, Eyes of Deceit, seed of thought and so on, assist the readers greatly to get a deeper interpretation of the texts. These literary tools bring out the beauty and uniqueness of African novels.

This paper has been able to establish that the influence of a particular text or author on another text or writer is not a denial of originality. This has been done through the analysis of some texts from African writers with a special attention on Fágúnwà's translated novels as a case study. Intertextuality has come to stay in African Literature. No literary artist could actually claim that there is no influence from other writers or works on his literary outputs in one area or the other and at one particular period or the other. Once there is acknowledgment by the author, the terrifying ghost of plagiarism is nailed to the cross. African writers, especially the upcoming ones have mastered this act and that has helped to develop the confidence and boldness of contemporary African writers and that has equally led to the global development of African Literature in general.

\section{References}

Adeniyi, D. 1994. Expedition to the Mount of Thought. Ilé-Ifẹ:: Ọbáfẹ́mi Awólọ́wọ̀ University Press. Bọdúndé, C. 1994. Studies in Comparative Literature. In New Introduction to Literature, Olú Ọbáfẹ́mi (ed.), 55-74, İbàdàn: Y. Books.

Conrad, J. 1902. Heart of Darkness. Harmondsworth, Middlesex: Penguin. 
1911. Under Western Eyes. Harmondsworth, Middlesex: Penguin.

Fagunwa, D. O. 1950. Ògbójú Ode Nínú Igbó Irúnmọlè. İbàdàn: Nelson and Evans Brothers, 2005.

(First published by the CMS Bookshop, Lagos 1938).

1949. Igbó Olódùmarè. İbàdàn: Nelson and Evans Brothers, 2005.

1949. İrèké-Oníbùdó. Edinburgh: Nelson.

1954. İrìnkèrindò Nínú Igbó Elégbèje. İbàdàn: Nelson and Evans Brothers, 2005.

1961. Àdìtú Olódùmarè. İbàdàn: Nelson and Evans Brothers, 2005.

Finnegan, R. 1970. Oral Literature in Africa. Oxford: Clarendon.

Izevbaye, D. 1982. "The African Experience of Comparative Literature". In Comparative Approaches to Modern African Literature, edited by S. O. Asein. Ibadan: Ibadan University Press. Jéyifò, B. 1988. Ben Okri. In Perspectives on Nigerian Literature, 1700 to the Present, Volume 2, edited by Yẹmí Ògúnbíyi, 277-281, Lagos: Guardian Books.

Kệhìndé, A. 2003. Intertextuality and the Contemporary African Novel, Nordic Journal of African Studies 12 (3): 372-386.

Kristeva, J. 1980. Desire in Language: A Semiotic Approach to Literature and Art. Translated by Thomas Gora, Alice Jardine and Leon S. Roudiez. Edited by Leon S. Roudiez, New York: Columbia University Press.

Murphy, D. (ed.). 2000. Sembene: Imagining Alternatives in Film and Fiction. Oxford: James Currey. Nwagbara, U. 2011. "Intertextuality and the Truth of Achebe's Fiction: Militarised Nigerian Postcolony in Anthills of the Savannah" The Criterion: An International Journal in English 2 (2): $1-19$.

Obafemi, O. 2012. The Mysteries of God. İbàdàn: Nelson.

Ogede, O. 2011. Intertextuality in Contemporary Literature, Looking Inward. London: Lexington Books.

Ogunsanwo, O. 1995. Intertextuality and Post-Colonial Literature in Ben Okri's The Famished Road. In Research in African Literatures 1 (26): 41-52.

Okri, B. 1992. The Famished Road. London: Vintage Books.

Randall, M. 2001. Pragmatic Plagiarism: Authorship, Profit and Power. Toronto: University of Toronto Press.

Sellers, H. 2007. The Practice of Creative Writing. Boston: Bedford / St. Martin's.

Shakespeare, W. 1996. Romeo and Juliet. In The Complete Works of William Shakespeare, 245-278, Oxford: Wordsworth Editions.

Sóyínká, W. 1976. Myth, Literature, and the African World. Cambridge: Cambridge University Press.

1982. The Forest of a Thousand Daemons: A Hunter's Saga. İbàdàn: Nelson. 2010. In the Forest of Olodumare. İbàdàn: Nelson. 